\title{
The Significance of International Corporate Governance Disclosure on Financial Reporting in Nigeria
}

\author{
Beredugo Sunny Biobele ${ }^{1}$, Igbeng Emmanuel Igbo ${ }^{1} \&$ Eze Felix John ${ }^{2}$ \\ ${ }^{1}$ Department of Accounting, University of Calabar, Cross Rivers State, Nigeria \\ ${ }^{2}$ Department of Marketing, University of Calabar, Cross Rivers State, Nigeria \\ Correspondence: Beredugo Sunny Biobele, Department of Accounting, University of Calabar, P.M.B. 1115, \\ Calabar, Cross Rivers State, Nigeria. Tel: 234-803-620-0517. E-mail: suntap2747@yahoo.com
}

\author{
Received: October 30, 2012 Accepted: December 13, 2012 Online Published: March 22, 2013 \\ doi:10.5539/ijbm.v8n8p100 URL: http://dx.doi.org/10.5539/ijbm.v8n8p100
}

\begin{abstract}
The adjudication for International corporate governance disclosure framework, such as, the International Standard of Accounting and Reporting (ISAR), has assumed a state of relevance between local and international markets participants, to circumvent the encumbrances of incomparable corporate governance disclosures despite the integrations of commercial activities around the world. The study, therefore, examined the significance of international corporate governance disclosures on financial reporting in Nigeria. Content analysis design was adopted, while population t-test and multiple regressions were used for hypothetical tests. It was however discovered that, International Corporate Governance disclosures significantly affects companies' total assets and profitability, and that, Nigerian Banks report more than half the ISAR requirements, but was done indiscriminately. It is therefore recommended that, relevant codes of corporate governance in Nigeria be upgraded to reflect international specifications and the remiss of good governance be done away with, if we must achieve anti-corruption and investment drive. ISAR should be adopted and sanctions meted for non-compliance. Where this is done, organizations will have access to capital from international stock market and expansion of their business across boundaries. This will eventually breed economic viable Nigeria, free off corruption, and the actualization of the rebranding Nigeria ideology.
\end{abstract}

Keywords: international corporate governance, profitability, total assets, comparability, transparency

\section{Introduction}

Globalization resilience through international trades and investments among countries around the world, with the growing need for comparable information, is demanding credible corporate governance disclosures that reflect international perspective. It was however specified that, the proliferation of cross-border trade by MNEs has resulted in an increasing awareness (Kim, 2007), of corporate governance practices relating to control structure, and anti-fraud procedure. Investors are now paying much attention on corporate governance activities, using a recognized international framework as yardstick to evaluate reports on non-financial performance exigencies on conflicts of interest, compliance with applicable regulations/standards, risk management objectives, control structure, internal control, ethics, and emphasis on customer relations to enhance the company's reputation etc.

Stakeholders are showing more concern on propitious commercial practices, requesting more disclosures on governance, socio-economic and environmental issues.

Without prejudice, the reliability and comparability of information influence investment in an economy. Global investors are therefore not surprisingly promoting international corporate governance disclosure in companies largely in their own self-interest, due to the risk of opportunism inherent in the manager's influence in the firm, relayed as incomplete or distorted disclosure of information and calculated efforts to mislead, distort, obfuscate or otherwise confuse the public and shareholders (Okpara, 2010), which is dire on investment and organizational growth.

In recent times, the sharp practices and unethical dispositions of many directors and management of organizations, that came to light following investigations (Seyi, 2011), might have led to arrest and prosecutions, as was the situations sorrounding Mrs. Cecilia Ibru and Mr. Akingbola Erastus of the defunct Oceanic Bank and Intercontinental Bank of Nigeria respectively (Nigerian Eye, 2012). But the crux of the issue is that, their actions 
had consequentially led to the collapse of their banks, while investors' funds significantly impaired. This causes investors and other stakeholders to loose faith in most organizations, resulting in a negative effect on total assets, turnover and the profitability potentials of organizations. The reasons being the pervading culture of corruption and lack of institutional capacity to implement a credible code of corporate governance, that has also earned Nigeria a bad reputation and made private and institutional investors (local and foreign) hesitant to invest in the Nigerian economy due to the lack of transparency, accountability and comparability; propelled the then minister of communication and re-orientation (Prof. Dora Akunyili) to embark on the rebranding Nigeria propaganda.

However, the current global financial and economic crunch has also directed attention to improve and enforce financial reporting disclosures worldwide in order to reform the global economy. Though, the Nigerian capital market is presently undergoing some deep reforms, aimed at restoring waning investors' confidence (Oscar, 2011), that was rippled by acute vulnerability of the Nigerian market. For instance, the mismanagement in recent nationalized Banks in Nigeria, leading to their being take-over and licenses revoked, had a "heavy blow" on shareholders and negative effect on other stakeholders, such as the employees that lost their jobs; as they never saw it coming, neither was the internal problem made known. This no doubt indicates a bleak in corporate governance culture in among Nigerians, while organizations emulating good corporate governance, made their reports in an impoverished and indiscriminate manner, due to plethora of legal frameworks on corporate governance around the globe.

It therefore follows that, for corporate governance information to effectively meet the needs of both local and international recipients, it must be comparable within an entity through time and between different entities. Where this is done between entities, the information must comply with the requirement of a set of standard such as the International Standard of Accounting and Reporting (ISAR).

A credible legal framework on non-financial performance disclosure is no doubt essential for resource allocation and enhancement of corporate governance structure in Nigeria. Hedia, Amira, Jameleddine, \& Jaleleddine (2011) opined that, the exclusive use of financial performance measure has spawned a large gap in the system of performance measurement, and investors are concerned with issues on: directors' independence and composition, code of conducts, ownership structure and control and also their social responsibility. All these information affect decision making and policy formulation; just as accounting for organizations activities on the environment accentuates sustainable development in Nigeria (Beredugo \& Mefor, 2012).

Hence, to achieve a credible corporate governance disclosure to facilitate the acquisition of short and long term funds in and outside Nigeria, and also to enable management to properly account for the resources put in their care, requires standards that govern corporate governance disclosures in Nigeria be regulated at the national level to reflect international best practices. This is because of the different corporate governance frameworks in existence, together with plethora of voting rights (a one-share-one-vote policy, one-share-multiple-vote policy and one share-no-vote policy), wherein some shareholders degree of control is disproportionate to their equity ownership, yet, information on this arrangement is barely disclosed in an organization's annual report, making it deficient of vital information.

These shortfalls and many other corporate governance disclosure exigencies had been taken care-off by ISAR to cater for international corporate governance reporting that would ultimately lead to transparency, clarity, comparability and greater economic growth around the world as underscored in this paper.

It is against this backdrop we propose to evaluate the significance of international corporate governance disclosures on company's profitability and total assets and to examine the extent to which listed companies report on international corporate governance.

\section{Literature Review}

\subsection{Corporate Governance}

Company failures have highlighted the need for stakeholders to obtain assurance on governance (Pricewaterhousecoopers, 1999), because high profile corporate collapses have contributed to public mistrust and the demand for improved corporate governance, accountability and transparency (Kim, 2007).

Most organizations report gigantic profits, while withholding information on inherent risk and mismanagement that threatens organizations' going-concern. Succinctly, the absent of corporate governance disclosures, dissuades investment and capital inflow and also affects organizations' total assets, patronages for their goods and services and accruable profits.

Stakeholders are therefore, seeking increased information on corporate governance, because it affects profitability through consumer's patronage, reduces cost of capital and enhances the total assets through access to capital. 
Researchers of both local and international reputes are also of the view that the basic means of restoring investors' confidence is the need for a single framework on corporate governance disclosure to ensure transparency, accountability and comparability (Siems, 2005).

The emulation of good corporate governance will not only restore investors' confidence but also attract global investors; just as IFRS for financial statements enhance comparability and serves as fraud-proof amongst other functions, the adoption of ISAR guidelines for corporate governance disclosure would further guarantee transparency, integrity, fairness and accountability on material matters on performance, control, ownership, and governance of the companies.

Inyang (2004) opined that, the current issues of globalization and information communication technology facilitate business transactions around the world. These developments necessitate the evolution of international business standards to guide business operations across nations, improving corporate performances and to benefit all stakeholders (Elebute, 2000). In the same vein, Kolade (1999) specified that, when corporate governance principles are evolved and international standards are set, investors' and creditors' confidence would be enhanced and the regulatory agencies would be sufficiently empowered to handle monitoring responsibility in their different companies. This is because corporate governance deals with the ways in which suppliers of finance to corporations, assure themselves of getting a return on their investment (Denis, \& McConnell, 2003). Kwaka \& Nzekwu, (2003) put it as the manner in which the power of a corporation is exercised in the stewardship of the corporation's total assets and resources with the objectives of maintaining and increasing shareholders value and the satisfaction of other stakeholders in the context of its corporate mission.

While, Mueller (1981) refers corporate governance as sets of mechanisms that influence the decisions made by managers when there is a separation of ownership and control. Shil (2008) posits that, good corporate governance increases public confidence in a corporation, and lowers the cost of capital for investment.

\subsection{International Corporate Governance (ICG) Disclosure}

Corporate governance has become an issue of sustainable competitive advantage. Poor corporate governance is now a route to organizational failure. One bad decision, or a right decision poorly explained and communicated, can do untold damage to an organization's reputation where, only a few years ago, it might have either gone unnoticed or been accepted unchallenged (Kai, Kurt, Marylou \& Vinay, n. d).

A credible disclosure on governance is vital for allocation of resources. For example, the lemons problem arises where investors cannot distinguish between good and bad ideas; they will value both good and bad ideas at an average level (Okpara, 2010). It is therefore expected that a credible and widely acceptable disclosure framework with international presence would enhance corporate governance structure in Nigeria.

The quality of disclosure depends significantly on the robustness of the reporting standards on which the financial information is prepared and reported (UNCTAD, 2006).

The choice of ISAR, as an international legal framework to meet disclosures requirements, is not out of place, since, Nigeria is a member of UNCTAD. The UNCTAD/ISAR list of best practices on corporate governance disclosure has also been developed on the basis of the consensus achieved on what constitutes adequate transparency, and comparable corporate governance disclosures. It is also acknowledged that more guidance at the international level is needed in order to ensure practical implementation on points agreed (UNCTAD, 2003).

The convergence to single international corporate governance reporting is no doubt imperative; Zabiholiah (n. d.) noted that, different types of corporate governance structure exist and are exposed to different financial misconduct and scandals. For example, the dispersed ownership system of governance in the United States is prone to earnings management schemes (e.g., Enron, WorldCom), whereas concentrated ownership systems are more vulnerable to the appropriation of private benefits of control (e.g., the case of Cecilia Ibru of Oceanic Bank of Nigeria).

In addition, in spite of the bringing together of commercial activities among nations, corporate governance disclosures are still done in an indiscriminate and impoverished manner.

Matoussi \& Khemakhem (2012) opined that, companies share the same imperatives: the ability to raise new capital, the efficiency of resource allocation, the growth of firm value, and the availability of information to all decision makers. These imperatives drive countries and firms in both advanced and emerging economies to adopt the same and the most efficient corporate rules and structures. While the demand for more information on corporate governance disclosure issues is becoming increasingly sophisticated, with greater calls for concise and comparable reports. 
However, convergence to ISAR as a benchmark on international corporate governance disclosure would accentuate transparency of report, taking into consideration the materiality of the non-financial performance indicators to end users and will encourage the restoration of investors' confidence, access to capital, transparency and patronages from all stakeholders.

\section{Research Methodology}

The content analysis was applied using the annual reports of selected banks in Nigeria. Each annual report was carefully scrutinized and scored as a disclosure index based on a researcher-developed checklist. The disclosure index method was seen by researchers in time past (Singhvi \& Desai, 1971), as an adequate model for financial reporting evaluation and have been used over time.

A total number of 10 banks were used for the analyses. These banks include: First Bank Nig. Plc. (FBN), Zenith Bank Nig. Plc., Diamond Bank Nig. Plc., Union Bank Nig. Plc., Guarantee Trust Bank (GTB), Access Bank Plc., Eco Bank Nig. Plc., Stanbic IBTC Bank Plc., First City Monument Bank (FCMB) Nig. Plc., and United Bank of Africa (UBA).

\subsection{Sources of Data}

The secondary sources of data consist of the '2011' annual audited reports, and "ISAR" issued by (UNCTAD, 2006).

\subsection{The Researcher's Checklist}

The researcher's checklist was constructed based on the information items of ISAR guidelines under five (5) headings: Board and management structure and process, ownership structure and exercise of control rights, auditing processes, and corporate responsibility and compliance.

\subsection{The Scoring Procedure for Disclosure Indexes}

The research adopted the unweighted approach for the scoring. It is preferred because each items of disclosure is equally important, it reduces subjectivity and it provides a neutral assessment of items. This approach uses a dichotomous procedure to develop a scoring scheme that captures the level of corporate governance disclosure. Complete annual report for each company was reviewed in order to understand the nature and complexity of each company's operation and to form an opinion about the company before scoring the items.

Each reporting item on the checklist is assigned a value of ' 3 ' if it is reported with high details, ' 2 ' ' if it is reported with medium details,' 1 ' if it is reported with low details and ' 0 'if the item is assumed relevant but not disclosed. The score (index) for each standard heading is the ratio of actual disclosure divided by applicable disclosure.

The full specification of the regression equations are assumed to be as follows:

$$
\begin{aligned}
& T A_{j}=\boldsymbol{\beta}_{0}+\boldsymbol{\beta}_{I} I C G+\varepsilon_{j} \\
& P A T j=\boldsymbol{\beta}_{0}+\boldsymbol{\beta}_{I} I C G+\varepsilon_{j}
\end{aligned}
$$

The samples used were from the banking sector due to their early compliance with corporate governance disclosure, and because the financial sector is highly regulated due to its contribution to the economy and it is expected to disclose more detailed information than the other industries. The banking sector accounts for 65 percent of the market capitalisation of the Nigerian Stock Exchange (Reuters, 2009).

Two hypotheses were evaluated, for hypothesis one, regression analysis was utilized using "2011" financial report of the companies as a base and the diagnostic test conducted was the Durbin-Watson. While the population t- test was used on hypothesis two.

\section{Research Results and Findings}

The comparative analysis of the financial reports of the companies used on international corporate governance disclosures are presented below:

\section{Hypothesis 1}

$\mathrm{H}_{\mathrm{o}}$ : International corporate governance disclosure does not significantly affect companies' total assets and profitability.

$\mathrm{H}_{1}$ : International corporate governance disclosure significantly affects companies' total assets and profitability. 
Table 1. Model summary

\begin{tabular}{lcccccc}
\hline Model & & $\mathrm{R}$ & $\mathrm{R}$ Square & Adjusted R Square & Std. Error of the Estimate & Durbin-Watson \\
\hline Equation 1 & TA & $.875^{\mathrm{a}}$ & .760 & .747 & $6.80932 \mathrm{E} 5$ & 1.691 \\
Equation 2 & PAT & $.857^{\mathrm{a}}$ & .735 & .702 & 8770.78996 & 1.621 \\
\hline
\end{tabular}

a. Predictors: (Constant)

b. ICG_Disclosure

Table 2. Regression results for equation 1

\begin{tabular}{llccccc}
\hline \multirow{2}{*}{ Model } & \multicolumn{2}{c}{ Unstandardized Coefficients } & \multicolumn{2}{c}{ Standardized Coefficients } & & \\
\cline { 2 - 5 } & $\mathrm{B}$ & Std. Error & Beta & $\mathrm{t}$ & Sig. \\
\hline 1 & (Constant) & -749298.308 & 1037588.608 & & -.722 & .491 \\
& ICG_disclosures & 11129412.74 & 2792125.626 & .575 & 3.986 & .032 \\
\hline
\end{tabular}

a. Dependent Variable: TOTAL_ASSETS

Table 3. Regression results for equation 2

\begin{tabular}{llccccc}
\hline \multirow{2}{*}{ Model } & \multicolumn{2}{c}{ Unstandardized Coefficients } & \multicolumn{2}{c}{ Standardized Coefficients } & & \\
\cline { 2 - 4 } & & $\mathrm{B}$ & Std. Error & Beta & $\mathrm{t}$ & Sig. \\
\hline 1 & (Constant) & -38604.230 & 13364.722 & & -2.889 & .020 \\
& ICG_disclosures & 169378.822 & 35964.140 & .857 & 4.710 & .002 \\
\hline
\end{tabular}

a. Dependent Variable: PAT

As shown in table 2, the t-statistics for equation 1 is positive ICG and it is significant $5 \%$ with a t-value of 3.986 . The t-statistics for equation 2 (table 3 ) is also positive ICG at 5\% significant with a t-value of 4.710 .

From table 2 the $\mathrm{R}^{2}$ Value of about 0.76 for equation 1 and 0.74 for equation 2 means that 76 percent of the variation in total assets is explained by the international corporate governance disclosure; while 74 percent of the variation in PAT is explained by the international corporate governance disclosure. For the Durbin-Watson test, the figures for equation 1 and 2 were 1.691 and 1.621 respectively. This does not pose a threat of independent errors since these figures were not far from 2.

Table 4. Summary of hypothesis 1 results

\begin{tabular}{lccccccc}
\hline Independent Variable & \multicolumn{2}{c}{ Expected Sign } & \multicolumn{2}{c}{ Reported Sign } & Significant or & Accepted/Rejected \\
& \cline { 2 - 5 } & TA & PAT & TA & PAT & Not Significant & \\
\hline ICG disclosures & + & + & + & + & Sig & Accepted \\
\hline
\end{tabular}

Source: Field study, 2012

International corporate governance is found to significantly affect both total assets and PAT $(p<0.05)$ indicating that Banks in Nigeria are conversant with the international corporate governance reporting. Thus $\mathrm{H}_{1}$ is retained.

\section{Hypothesis 2}

$\mathrm{H}_{\mathrm{o}}$ : the extent to which companies report on international corporate governance is significantly low.

$\mathrm{H}_{1}$ : the extent to which companies report on international corporate governance is significantly high.

Using the population $t$ test denoted as: $\frac{\mu-x}{\operatorname{SD} / \sqrt{n}}$

Where: $\mathrm{x}=$ mean of the samples 
$\mu=$ assumed mean of the population

$\mathrm{SD}=$ standard deviation of the samples

$\mathrm{n}=$ number of companies

Table 5. Descriptive statistics

\begin{tabular}{llcc}
\hline & N & Mean & Std. Deviation \\
\hline Companies & 10 & 57.8000 & 12.92543 \\
Valid N (listwise) & 10 & & \\
\hline
\end{tabular}

Source: Field study, 2012

$$
\mathrm{t}=\frac{79.5-57.8}{13 / \sqrt{10}}=5.2798
$$

At a significant level of 0.05 using the $1 \mathrm{~d}$. f., the $\mathrm{t}$ - tabulated was 1.83 while the calculated $\mathrm{t}$ value: 5.2798 . It therefore means that the $\mathrm{H}_{0}$ is rejected and the $\mathrm{H}_{1}$ which specifies that the extent to which companies report on international corporate governance is significantly high was accepted.

\section{Discussion of Findings, Conclusion and Recommendations}

The main findings show that, International corporate governance disclosures significantly affect companies' total assets and profitability, and that the extent to which banks report on international corporate governance is significantly high, though carried out in an impoverished manner.

These effects cannot be overemphasized, as investor's confidence in the global financial markets is the key driver to economic growth, global competition, financial stability and increased total assets. In the same vein, stakeholders - financial institutions, Business partners, and customers - patronize organizations for engaging in international best practice on financial reporting to include corporate governance disclosures with information on board and management structure and process, ownership structure and exercise of control rights, auditing processes, and corporate responsibility and compliance. However, inasmuch as business survival is also at the mercies of consumers' patronages which have a hold on its economic benefits (profitability), consumers are demanding for concise and comparable reports on organizations' responsibility to them. UNCTAD (2006) specifies that, the organization is expected to report on product safety measures, product quality, and product liability.

The findings further signify that, a credible legal framework on non-financial performance disclosure is essential for resource allocation and enhancement of corporate governance structure in Nigeria, as financial information alone is not sufficient for making informed economic decision on an organization (Hedia, et. al., 2011). And that, just as financial statements disclosure requires IFRS to be understandable, relevant, reliable and comparable; a set of globally accepted corporate governance measures is essential (Zabiholiah, n. d.), to enhance transparency, reliability and comparability on corporate governance disclosures.

It is therefore recommended that, the relevant codes of corporate governance in Nigeria be upgraded to reflect international specifications - such as ISAR - and the remiss of good governance be done away with by the Nigerian public and private sectors, if we must achieve anti-corruption and investment drive.

The use of ISAR should be adopted in Nigeria, as a legal framework to be followed by ministries, departments and agencies as well as private sectors to account for their activities on governance, while non-compliance should attract sanctions from relevant authorities such as the NSE, SEC and the CBN. More so, the clarion calls for the convergence of the different corporate governance disclosure frameworks in the world should not be taken lightheartedly.

Capacity building measures should also be put in place to raise awareness on international corporate governance disclosure and its associated benefits. Where all these are done, credible corporate governance reporting will be ensured, ultimately leading to transparency, clarity, comparability of the non-financial information. Investors' confidence will also be restored, and Nigerian's image revamped, causing organizations to have unrestricted access to capital from both local and international stock market, which would somewhat breed an economic viable Nigeria, and greater economic growth, free off corruption, and the actualization of the rebranding ideology and Nigeria will be investors' destination. 


\section{Refernces}

Beredugo, S. B., \& Mefor, I. P. (2012). The impact of environmental accounting and reporting on sustainable development in Nigeria. Research Journal of Finance and Accounting, 3(7).

Denis, D. K., \& McConnell, J. J. (2003). International corporate governance. ECGI Working Paper Series in Finance, Working Paper $\mathrm{N}^{\circ}$ 05/2003.

Elebute, K. (2000). Corporate governance, reporting and shareholders value. Business \& Management Journal, 3, 8-19.

Hedia, T., Amira, K., Jameleddine, C., \& Jaleleddine, B. R. (2011). Impacts of tax incentives on corporate financial performance: the case of the mechanical and electrical industries sector in Tunisia. International Journal of Economics and Finance, 3(6). http://dx.doi.org/10.5539/ ijef.v3n6p117

Inyang, B. J. (2004). Corporate Planning and Policy: Concepts and Application. Calabar: Merb Publishers.

Kai, P., Kurt, A., M, S., \& Vinay, D. (n.d.). Diversity and Corporate Governance. Ashridge Business School http://www.ashridge.org.uk

Kim, K. (2007). Corporate social responsibility - Impact of globalization and international business. Corporate Governance E- Journal.

Kolade, C. (1999). Working for Business Integrity in Nigeria. The roles of professional Management in Nigeria, pp. 5-11.

Matoussi, H., \& Jardak, M. K. (2012). International corporate governance and finance: Legal, cultural and political explanations. The International Journal of Accounting, 47, 2-3.

Nigerian Eye. (2012). House of Reps. wants Ibru, Akingbola Stripped of National award. Retrieved from Http://www.nigerianeye.com/2012/07/house-of-rep-want-ibru-aking

Okpara, J. O. (2010). Perspectives on corporate governance challenges in a Sub-Saharan African economy. Journal of Business \& Policy Research, 5(1), 110-122.

Oscar, O. (2011). Nigerian stock market operators get corporate certificate. The Business Eye: Nigerian's Investment Business Journal, 5.

Price water house coopers. (1999). Student's Manual of Accounting: the guide of UK Accounting and Practice. International Thomson Business Press.

Reuters, S. (2009). Nigeria's First Bank, Access Bank adopt IFRS. Retrieved 30 May from http://www.reuters.com/article/rbssbanks/

Seyi, L. (2011, April 27). Report: Nigeria records second highest number of fraud cases in Africa.

Shil, N. C. (2008). Accounting for good corporate governance. JOAAG, 3(1).

Siems, M. (2005). What does not work in securities law: A critique of La Porta et al.'s Methodology. International Company and Commercial Law Review, 7, 300-305.

Singhvi, S. S., \& Desai, H. B. (1971). An empirical analysis of the quality of corporate financial disclosure. The Accounting Review, 46(1), 129-138.

UNCTAD. (2003). Major issues on implementation of corporate governance disclosure requirements. 2003 review, Report by the UNCTAD secretariat of the United Nations Conference on Trade and Development. Retrieved from http://.auditcommission.gov.uk/health/audit/financial

UNCTAD. (2006). Guidance of Good Practices in Corporate Governance Disclosure. United Nations Publication.

Zabiholiah, R. (n.d.). Corporate Governance and Ethics: Emerging Issues in Corporate Governance. The University of Memphis. 